$\xi=-1$

\title{
Rehabilitation of Beam Column joint using Steel Fibrous Concrete
}

\author{
A. Anoop Kumar ${ }^{1 *}$, V. Ranga Rao ${ }^{2}$, M. Achyutha Reddy ${ }^{3}$ \\ ${ }^{1}$ MTech student, Civil Engineering Department, Koneru Lakshmaiah Education Foundation, Guntur, India. \\ ${ }^{2}$ Professor, Civil Engineering Department, Koneru Lakshmaiah Education Foundation, Guntur, India. \\ ${ }^{3}$ Ph.D. Scholar, Civil Engineering Department, Koneru Lakshmaiah Education Foundation, Guntur, India. \\ *Corresponding author E-mail: ambatianoop@gmail.com
}

\begin{abstract}
An experimental study was conducted to compare the structural behavior of beam column joint before and after rehabilitation by using fibrous concrete with steel fibers as a strength enhancer material. Two specimens were examined in this study out of which one was designed according to IS 456: 2000 (control specimen) codal provision and another one was designed according to IS 13920:2016(ductile specimen). Both the supports at top and bottom faces of the column were hinged, and the load was applied on the edge of the beam. The parameter observed during the experiment was Load- deflection response for both control and rehabilitation specimens. The ultimate load carrying capacity for rehabilitated controlled specimen increased by $36.6 \%$ in comparison with controlled specimen, and the ultimate load carrying capacity for rehabilitated ductile specimen increased by $62.3 \%$ in comparison with ductile specimen. It has been observed that steel fiber reinforced concrete can enhance flexural strength, ductility and crack arrest.
\end{abstract}

Keywords: Beam column joint, Ductility, Flexural strength, Rehabilitation, Steel fibers

\section{Introduction}

The Beam Column joint (BCJ) is critical zone in reinforced concrete frame. Especially, when they are subjected to the earthquake forces its behavior has a significant influence on the response of the structure. The BCJ plays a prominent role in transfer of gravity loads and energy dissipation. Generally, when earthquake occurs, joints are severely damaged which makes the structure weak.

Buildings must be designed to withstand the earthquakes to reduce the damage on the structure after the earthquake. To resist lateral force, the ductile detailing must be provided in the reinforced concrete moment resisting frame. Inadequate transverse shear reinforcement in BCJ has proved to be deficient and after earthquake joint will experience brittle shear failure. So, for a better performance of a BCJ, ductile detailing is important under earthquake loads.

The process of restoring the structures to service level for what it was designed previously is called as Rehabilitation. Materials that are used for rehabilitation are fibers made of steel, carbon,

glass, polypropylene. With the application of new material alternatives like steel fibers, properties like tensile strength, flexural strength, shock resistance, fatigue resistance, ductility and crack arrest can be improved in BCJ.

A structure designed using IS-456: 2000 [1] does not provide sufficient safety and stability during earthquakes as failure occurs in brittle nature due to insufficient ductile reinforcement. In order to withstand earthquake forces, a structure must be designed using IS-13920: 2016 [2] which provides necessary ductile reinforcement.
Yung-Chih [3] investigated on the full scale one-way Beam column joint. The BCJ both interior and exterior the RC jacketing were done. The results obtained proved that the exterior has given better seismic performance. The jacketing of BCJ has improved the stiffness, strength and ductility. Romanbabu [4] investigated on the three one third scaled specimens that are detailed as per IS13920. The three specimens out of which one is conventional, and other two with the in-cooperation of polyproline and steel fibers. The results concluded that the specimens incorporated with fibers had more stiffness, ductility compared to conventional. Bindhu [5] experimented on the four one third specimens two detailed with IS-456 and SP-34 and other two with IS-13920 and tested under reverse cyclic loading. Increase in Column axial load will improve the joint stiffness and load carrying capacity. The results concluded that the IS-13920 has more energy absorption capacity than the other specimens. Vikrant [6] studied on the performance of steel fiber in reinforced concrete, they have the sustainable and longlasting nature so they are widely used, the addition of steel fibers will reduce the workability to solve this problem, superplasticizers must be added without effecting the properties of concrete. Usha [7] conclude that after the addition of steel fibers to concrete, the failure mode changed from brittle to ductile, so steel fibers can be used to increase tensile strength and achieve ductility in the places where reinforcement cannot be used. Chaitanya Kumar [8] compared the effect of glass and steel fibers in concrete and concluded that by addition of steel fibers the strengths like compressive, flexural and split tensile are increasing linearly with increase of fibers, but up to $1 \%$ addition of glass fiber the strength is increasing and from $2 \%$ it is decreasing. 


\section{Description of the Specimen}

Two, one third scaled specimens of BCJ are designed as per IS456(2000) and IS-13920(2016). The specimen designed according to IS-456 is the Control Specimen(CS) and the specimen designed according to the IS-13920 is the Ductile Specimen(DS). The cross-sectional dimensions of the two specimens was same(Table:1). The column designed was $1000 \mathrm{~mm}$ in length and the cross section provided was $150 \mathrm{~mm} \times 200 \mathrm{~mm}$, while for the beam is of length $375 \mathrm{~mm}$ with cross-section of $200 \mathrm{~mm} \times 150 \mathrm{~mm}$. IS-456 code specified specimen has 4 number of high yield strength deformed bars of $16 \mathrm{~mm}$ diameter was used as reinforcement in column and for the beam 3 bars of $16 \mathrm{~mm}$ on top and 2 bars of $12 \mathrm{~mm}$ at bottom. The 7 No's of $8 \mathrm{~mm}$ Dia. was used as lateral ties with spacing of $150 \mathrm{~mm} \mathrm{c} / \mathrm{c}$ spacing in Column and 4 No's of $8 \mathrm{~mm}$ Dia. with spacing of $130 \mathrm{~mm} \mathrm{c} / \mathrm{c}$ in beam. In IS13920 specified specimen has 4no's of $16 \mathrm{~mm}$ Dia. was used as reinforcement in the column and 3 bars of $16 \mathrm{~mm}$ on top and 2 bars of $12 \mathrm{~mm}$ at bottom of the beam. The 15 o's of $8 \mathrm{~mm}$ Dia. used as lateral ties $150 \mathrm{~mm} \mathrm{c} / \mathrm{c}$ spacing in column and 9 No's of $8 \mathrm{~mm}$ Dia. at $130 \mathrm{~mm} \mathrm{c} / \mathrm{c}$ in beam. The detailing can be clearly seen in Figure: $1 \& 2$.

Table 1: Dimensions of all specimens

\begin{tabular}{|c|c|c|c|c|c|}
\hline \multicolumn{2}{|c|}{ Column dimensions(mm) } & \multicolumn{3}{c|}{ Beam dimensions(mm) } \\
\hline Length & Width & Depth & Length & Width & Depth \\
\hline 1000 & 150 & 200 & 370 & 150 & 200 \\
\hline
\end{tabular}

Design mix calculations were made as per Is 10262-2009, 53 grade ordinary Portland cement was used, coarse aggregate and fine aggregate confirming to zone-II was used. The specific gravities of cement, fine aggregate and coarse aggregates are 3.15, $2.324,2.782$. Target mean strength for M25 grade is $31.6 \mathrm{~N} / \mathrm{mm}^{2}$. The reinforcement details are shown in Table 2 and Table 3.

Table 2: Reinforcement detailing of column

\begin{tabular}{|c|c|c|c|c|c|c|c|}
\hline \multirow{2}{*}{$\begin{array}{l}\text { S. } \\
\text { N } \\
\text { o. }\end{array}$} & \multirow[t]{2}{*}{$\begin{array}{l}\text { Spec- } \\
\text { imen }\end{array}$} & \multicolumn{3}{|c|}{$\begin{array}{l}\text { Longitudinal rein- } \\
\text { forcement }\end{array}$} & \multicolumn{3}{|c|}{ Transverse reinforcement } \\
\hline & & $\begin{array}{l}\text { No. of } \\
\text { bars } \\
\text { \& Dia. }\end{array}$ & $\begin{array}{l}\mathrm{A}_{\mathrm{st}} \\
(\mathrm{m} \\
\left.\mathrm{m}^{2}\right)\end{array}$ & $\begin{array}{l}\mathrm{P}_{\mathrm{t}} \\
(\%)\end{array}$ & $\begin{array}{c}\text { No. of } \\
\text { bars\& } \\
\text { Dia. }\end{array}$ & $\begin{array}{c}\mathrm{A}_{\mathrm{st}} \\
(\mathrm{mm} \\
\left.{ }^{2}\right)\end{array}$ & $\mathrm{P}_{\mathrm{t}}(\%)$ \\
\hline 1 & $\mathrm{CS}$ & \multirow[t]{2}{*}{$\begin{array}{r}4- \\
16 \mathrm{~mm}\end{array}$} & \multirow{2}{*}{$\begin{array}{l}804 \\
.24\end{array}$} & \multirow{2}{*}{$\begin{array}{l}0.0 \\
27\end{array}$} & $7-8$ & $\begin{array}{c}351 . \\
85\end{array}$ & 0.018 \\
\hline 2 & DS & & & & $15-8$ & $\begin{array}{c}753 . \\
98\end{array}$ & 0.025 \\
\hline
\end{tabular}

Table 3: Reinforcement detailing of beam

\begin{tabular}{|c|c|c|c|c|c|c|c|}
\hline \multirow[t]{2}{*}{ S.No. } & \multirow{2}{*}{$\begin{array}{c}\text { Spe } \\
\text { ci- } \\
\text { men }\end{array}$} & \multicolumn{3}{|c|}{ Longitudinal reinforcement } & \multicolumn{3}{|c|}{$\begin{array}{l}\text { Transverse rein- } \\
\text { forcement }\end{array}$} \\
\hline & & $\begin{array}{c}\text { No. of } \\
\text { bars\& } \\
\text { Dia. }\end{array}$ & $\begin{array}{c}\mathrm{A}_{\mathrm{st}} \\
\left(\mathrm{mm}^{2}\right)\end{array}$ & $\mathrm{P}_{\mathrm{t}}(\%)$ & $\begin{array}{c}\text { No. of } \\
\text { bars\& } \\
\text { Dia. }\end{array}$ & $\begin{array}{c}\mathrm{A}_{\mathrm{st}} \\
(\mathrm{m} \\
\left.\mathrm{m}^{2}\right)\end{array}$ & $\begin{array}{c}\mathrm{P}_{\mathrm{t}} \\
(\%)\end{array}$ \\
\hline 1 & $\mathrm{CS}$ & $\begin{array}{c}\text { Top r/f } \\
3-\end{array}$ & 603.18 & 0.020 & $5-8$ & $\begin{array}{c}251 . \\
3\end{array}$ & $\begin{array}{c}0.00 \\
84\end{array}$ \\
\hline 2 & DS & $\begin{array}{l}16 \mathrm{~mm} \\
\text { Bottom } \\
\text { r/f } \\
2- \\
12 \mathrm{~mm}\end{array}$ & $\begin{array}{l}226.19 \\
0 .\end{array}$ & $\begin{array}{l}0.007 \\
5\end{array}$ & $9-8$ & $\begin{array}{c}452 . \\
34\end{array}$ & $\begin{array}{c}0.01 \\
5\end{array}$ \\
\hline
\end{tabular}

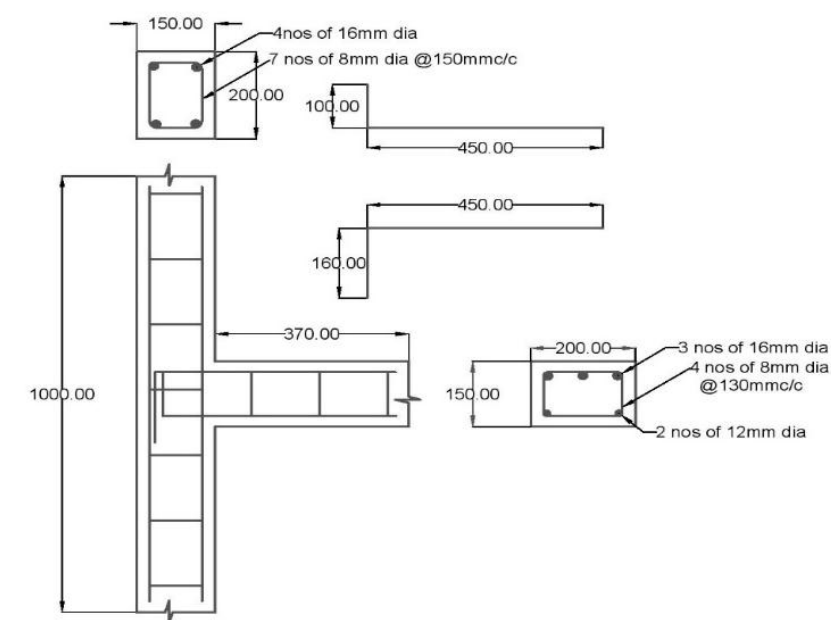

Figure 1: detailing of beam column joint using IS 456

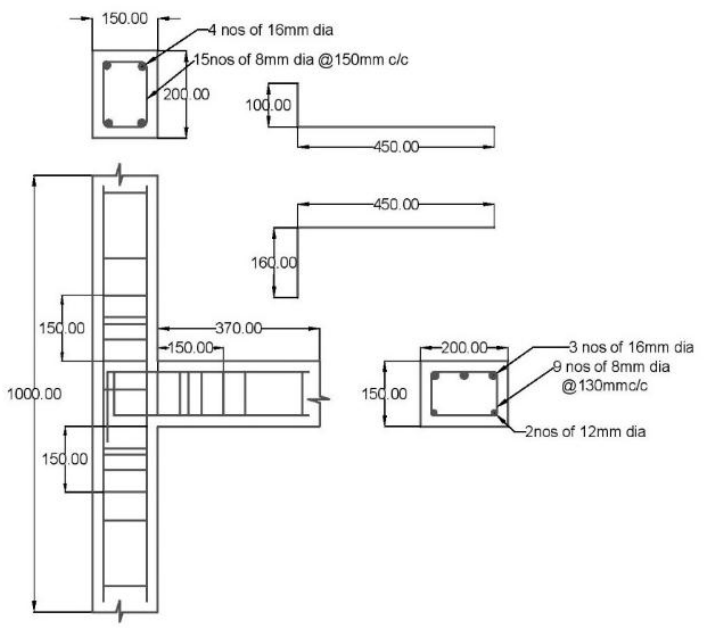

Figure 2: Detailing of beam column joint using 13920

\section{Loading Arrangement}

The schematic diagram of test-setup is shown in figure 3. The loading frame of 50tons capacity was used for testing the specimens. The column was placed vertically in the setup. An axial load of 20tons was applied to the column to represent gravity load. 2 hinge supports are used on both sides of the columns, the beam in BCJ is adjusted in such a way, that the hydraulic jack can apply load at the end of the beam. LVDT is arranged so as to get the load and its respective deflection of the beam.
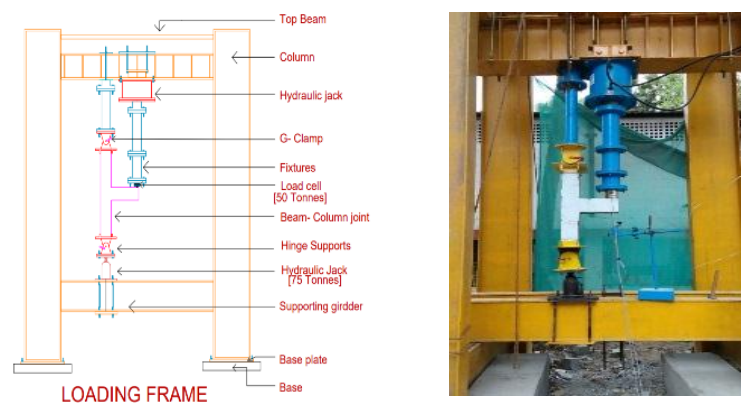

Figure 3: Beam column joint setup in loading frame.

\subsection{Testing of Control Specimen}

After the setup was completed in the loading frame, the control panel is made ready for obtaining results. With the help of loading cell, the load is gradually applied on the specimen, the displace- 
ments were recorded by LVDT, for a load of $12.4 \mathrm{kN}$ at a deflection of $26.58 \mathrm{~mm}$ the first crack was observed. After the initial crack, the load again applied on the specimen and the maximum load taken was $18.3 \mathrm{kN}$ at a deflection of $33.14 \mathrm{~mm}$.

\subsection{Testing of Ductile Specimen}

The testing arrangement of the specimen is shown in the Fig4, the load was applied gradually on the specimen. It was observed that for a load of $19.45 \mathrm{kN}$ and at displacement of $28.78 \mathrm{~mm}$, initial crack was start propagating at the intersection of beam column joint. For an ultimate load of $26 \mathrm{kN}$ and at a deflection of 32.04 $\mathrm{mm}$, cracks were started widening.

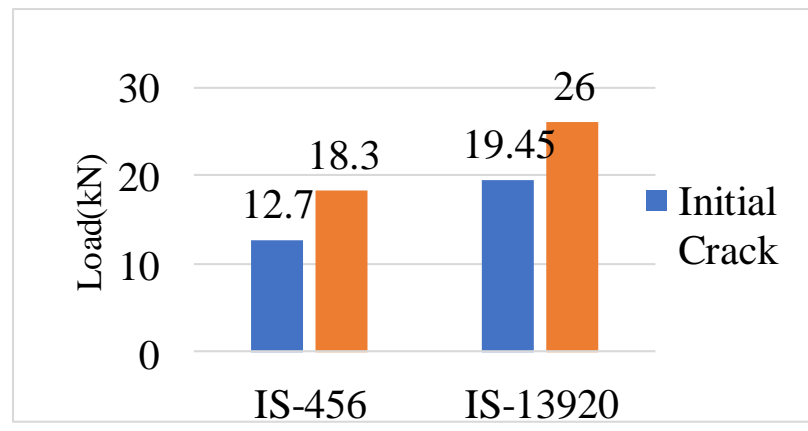

Figure: 4 Results of BCJ before Rehabilitation

\subsection{Rehabilitation of the Specimen}

The zone(place), where cracks were propagated is chipped off, as shown in Fig.5 the specimen is made free from loose particles after chipping off the cracked zone of concrete, then cement mortar is poured on the surface of concrete, where new concrete will contact older one for bonding. Then the rehabilitation material is added (steel fibers) to concrete in $2 \%$ of Volume fraction $\left(\mathrm{V}_{f}\right)$. Then the concreting is made to fill the zone of chipped area. Specimens were made ready for testing after the required time of curing period.

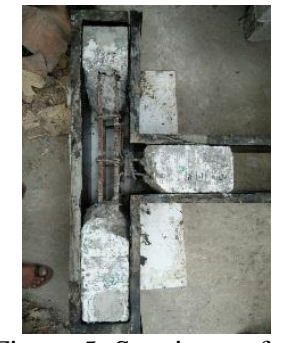

Figure 5: Specimen after chipping

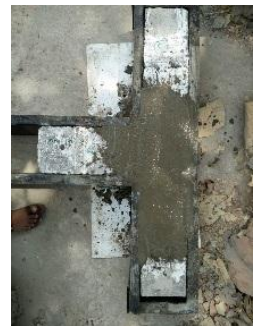

Figure 6: Specimen after rehabilitation

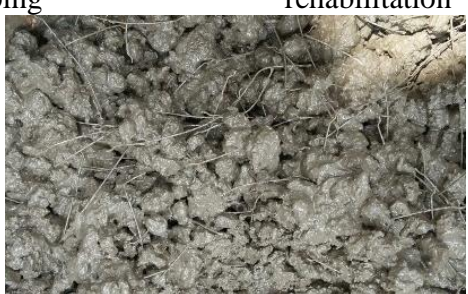

Figure 7: fibrous concrete

\subsection{Testing of Rehabilitated Controlled Specimen}

After the process of rehabilitation using fibrous concrete, and curing the specimens for the required time, the specimens have been tested under the same test setup as before. The first crack was observed at a load of $17 \mathrm{kN}$ for the deflection of $26.32 \mathrm{~mm}$. the ultimate load was $25 \mathrm{kN}$ for a displacement of 32 mm(Figure:8)
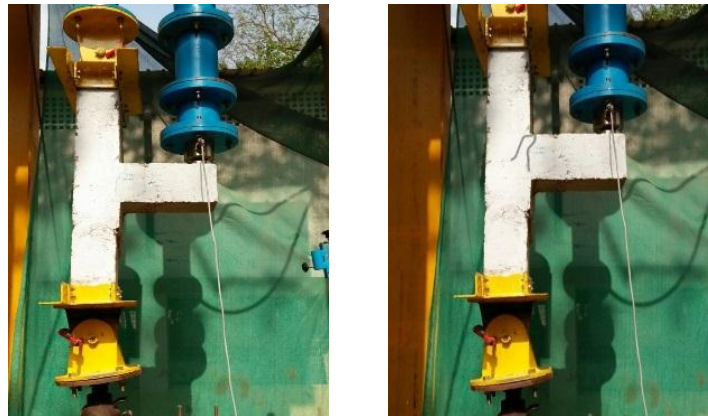

Figure 8: Control specimen before and after testing

\subsection{Testing of Rehabilitated Ductile Specimen}

After the process of rehabilitation using fibrous concrete, and curing the specimens for the required period, the specimens have been tested under the same test setup as before. The first crack was observed at $30.5 \mathrm{kN}$ with a deflection of $17.27 \mathrm{~mm}$ and the final crack was observed at $42 \mathrm{kN}$ at a deflection of $30.61 \mathrm{~mm}$ (Figure:9).
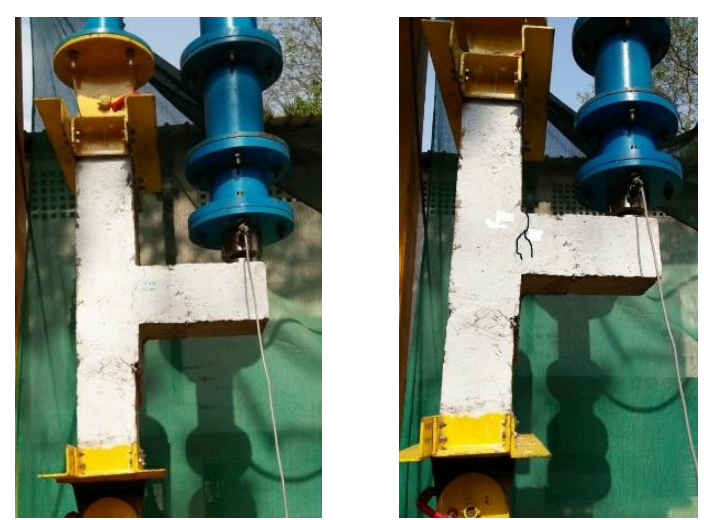

Figure 9: Ductile Specimen Before and After Testing

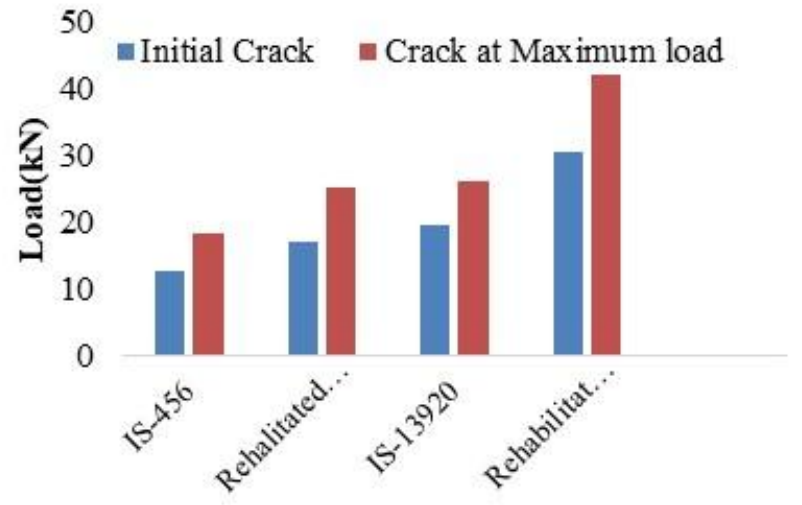

Figure 10: Crack Loads comparison

\subsection{Load vs Deflection}

The load carrying capacity of rehabilitated specimens were increased $36.6 \%$ for IS $456 \& 62.3 \%$ for IS 13920 . The maximum load taken by the conventional IS-456 was $18.3 \mathrm{kN}$ at deflection $25 \mathrm{~mm}$. The maximum load taken by Rehabilitated IS-456 was $25.8 \mathrm{kN}$ at deflection of $42.6 \mathrm{~mm}$ (Figure:11). The maximum load taken by the conventional IS- 13920 was $26 \mathrm{kN}$ at deflection $33.04 \mathrm{~mm}$. The maximum load taken by Rehabilitated IS-13920 was $21 \mathrm{kN}$ at deflection of $9.17 \mathrm{~mm}$ (Figure:12). 


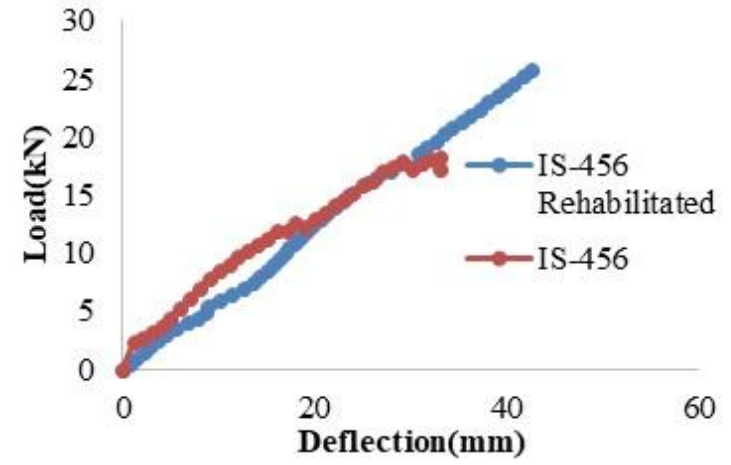

Figure 11: Load Vs Deflection graph of IS-456

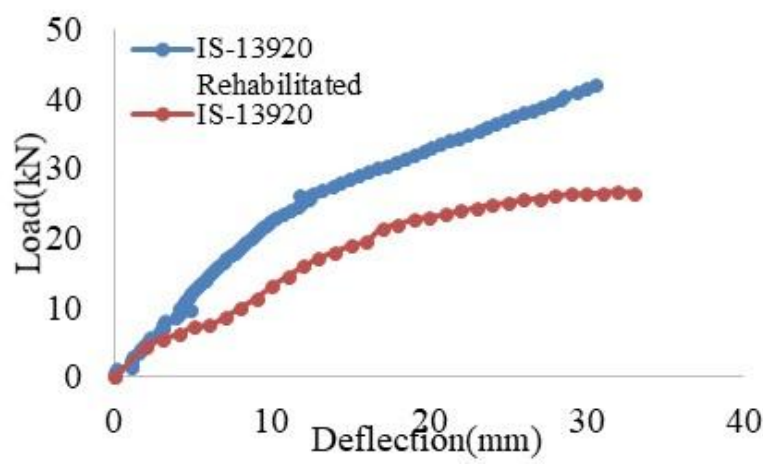

Figure 12: Load Vs Deflection graph of IS-13920

\section{Conclusion}

In this experimental study of beam-column joint, 2 scaled models were designed by using IS 456 \& IS 13920, these specimens were tested under point load until the ultimate load is reached and the propagated cracked zone of concrete was chipped off and rehabilitated by using steel fibrous concrete. And again, these rehabilitated specimens were tested under same loading condition, and the results were compared conclusions were drawn

- The addition of fibers played an important role in arresting and delaying propagation of crack.

- The load carrying capacity of rehabilitated specimens were increased $36.6 \%$ for IS $456 \& 62.3 \%$ for IS 13920 .

- Using steel fibrous concrete near BCJ failure mode changed from brittle to ductile.

- Based on the interpretation of results, the following

- This steel fibrous concrete can be used in critical areas for increasing tensile strength and to achieve ductility.

- This fibrous concrete is used for retrofitting and rehabilitation of structures so as to increase strength and ductility.

\section{References}

[1] IS-456(2000), Plain and Reinforced Concrete-Code of Practice, Bureau of Indian Standards, Manak Bhavan, 9 Bahadur Shah Zafar Marg,New Delhi.

[2] IS 13920:2016, Ductile Design and Detailing of Reinforced Concrete Structures Subjected to Seismic Forces - Code of Practice, Bureau of Indian Standards, Manak Bhavan, 9 Bahadur Shah Zafar Marg,New Delhi.

[3] Yung-chih WANG and ming-gin lee (2004), Rehabilitation of Nonductile Beam-Column Joint using Concrete Jacketing, $13^{\text {th }}$ world Conference of Earthquake Engineering, paper no 3159, pp:19, Canada

[4] Romanbabu M. Oinam, Choudhury.A.M, Laskar A I (2013), Experimental Study on Beam-Column Joint with Fibers Under Cyclic Loading, IOSR Journal of Engineering, Vol. 3, No. 7, pp: 13-23

[5] K.R. Bindhu, P.M. sukumar, K.P. Jaya (2009), Performance of Exterior Beam-Column Joints Under Seismic Type Loading, ISET Journal of Earthquake Technology, Vol. 46, No. 2, pp: 47-64, India
[6] Vikrant S. Vairagade, Kavita s. Kene (2012), Introduction to Steel Fiber Reinforced Concrete on Engineering Performance of Concrete, International Journal of Scientific \& Technology Research, Vol. 1, No.4, pp:139-141, India

[7] Usha M, P.Polujau (2018), Comparing Is Code Specified Flexural Strength Of Concrete With Split Tensile Strength by Conducting Test on Cubes, International Journal of Engineering \& Technology, Vol. 7, No. 2.1, pp:51-53,India

[8] E.Arunakanthi, J.D. Chaitanya Kumar (2016), Experimental Studies On Fiber Reinforced Concrete (FRC), International Journal of Civil Engineering and Technology, Vol. 7, No. 5, pp:329-336, India

[9] Song P.S. and Hwang s (2004), Mechanical Properties of HighStrength Steel Fiber Reinforced Concrete, Construction and Building Materials, pp 669-676.

[10] Nataraja M.c , Dhang N. and Gupta A.P, (1998), Steel Fiber Reinforced Concrete Under Compression, The Indian Concrete Journal, Vol. 26, No. 3, pp 353-356, India 